\title{
The Kingdom of Lettering: The Films Titles in the Early Years of Turkish Cinema
}

\author{
Nazlı Eda Noyan \\ Bahçeşehir University, Istanbul, Turkey
}

\begin{abstract}
This paper explores the film title design in Turkish cinema with the aim of understanding the link between Turkish cinema and Turkish graphic design. It is carried through first with the interviews with producers, directors, title designers, and an extensive use of iconography and textual analysis has been made first between the title and the poster of the same film, and then the titles of the same period. The study focuses on the early period of Turkish cinema during a unique time of political, economical, and social change. In these years, the new Turkish Republic is born with very significant reforms such as the new alphabet. This has also been the time of the first fictional film, first sound film, and the first advertising agency and commercial poster in Turkish. The earliest title sequence that could be reached date back to 1932 . From this year on, until the 1950 s, which is named here as the early years of Turkish cinema, we see the kingdom of lettering where the typographic elements dominate the titles. During the kingdom of lettering, early Turkish film titles reflect the conditions of the time in terms of film production and the changing society. The paths of Turkish cinema and graphic design seem not to be fully crossed yet; nevertheless we witness the birth of a new visual form and a new nation in these titles.
\end{abstract}

Keywords: film titles, Turkish cinema, graphic design, typography

\section{Introduction}

When the author was a graphic design major at the university, she was blown away by the titles of the crime thriller Se7en (1995) by David Fincher. It was graphic design immersed in film. It was typography and motion in harmony, experimental, and groundbreaking. The author had discovered a new path in her profession. Years later, the author developed an interest for Turkish cinema and she wrote her master's thesis on Turkish melodrama posters (1999). Then one day the author came across the title sequence of an action film from the 1970s and this time she was blown away by the title design. It was made up of well-crafted photo collages with simple but yet surprisingly innovative and very dynamic visual effects. Could this be expected from Turkish cinema, could Turkish cinema do that?

Moving images supported with graphic design has become one of the most inspirational and innovative areas of production of our time. The research that has been done on this subject generally discusses the technological dimensions of the film titles or leading non-Turkish film title designers. Because of the limitation of written sources and visual archives, the author developed her study with interviews made with professionals

Nazlı Eda Noyan, lecturer, Faculty of Communication, Bahçeşehir University. 
such as directors, producers, designers, and historians, who served Turkish cinema with different approaches and witnessed the process of film title production. The author also carried out her own archive research into film titles from different periods of Turkish cinema.

The method used in this paper for analyzing the titles benefits from Panofsky's (1983, originally published in 1939 in studies in iconology) iconography that he used to analyze art works. Mueller (2006) explained that visual analysis in mass communication and mass media research has in the past mainly been drawing on concepts originating either in the social sciences or in psychology; and the copious tradition of art history has not crossed this disciplinary line yet. On the other hand, van Leeuwen (2001, p. 101) showed the value of iconography by elaborating on examples of applying it to contemporary images. Panofsky's (1983) iconographical analysis has three phrases: (1) pre-iconographic description: the work's pure form devoid of any added cultural knowledge; (2) iconographic analysis: the relationship of visual elements with each other, figure-ground, hierarchy, style, and the theme drawn from these; and (3) iconographic interpretation: personal, technical, and cultural understanding of a work; the symbolic meaning or the possible intended meaning created by the designer. Iconographical analysis as reformulated by van Straten (1994, p. 16) has one more phrase added: iconological interpretation: deeper meaning not explicitly intended by the designer.

\section{Film Title as a Channel}

By becoming clues leading to the atmosphere and visual character of the film, film titles have become an important area of the film industry in terms of their contributions to film narration and the experience of film watching. Film-title pioneer Bass (2001), who defined himself as a graphic designer and film director, considered film titles as a foreword that contributes importantly to the process of storytelling. For him, the opening credits are a preparation before the film and the end credits is a decomposition chamber in which the audience gets over the influence of the adventure. Is the film title really an interim period which provides the break away from reality or is it pointing at the unreal nature of the film itself? The film title can enter and exit the diegetic (belonging to the world of the movie) and the non-diegetic (not belonging to this world) environments. The traditional separation of film titles from the film's field of narration occurs in two ways, which is also frequently observed in Turkish cinema: The titles are placed in a background independent from the film which is either a black or textured background; or the title is placed on the picture with superposing techniques. However, this is made in such a way that the title space and the pictures in the background do not seem connect to each other and they let us know clearly that it is disconnected with the film's narration world.

An argument, which Allison (2006) tried to prove the opposite of with examples, is in parallel with the prejudice that is also valid for the Turkish cinema. This argument is also many studies' point of origin regarding film titles: The history of film titles gained creativity and innovation with the works of Bass; before him, the titles were inefficient and conservative. According to Allison, the history of striking film titles dates back even to the 1910s, nevertheless, considering the film title not only as a list of names, but rather an area of expression with different styles and techniques is first seen especially in the 1930s. The reasons Bass's works are considered milestones in the film title design might be because he designed film titles as short films within themselves, his intense usage of rhetoric in graphic expression, or his success of forming an identity which spreads over all the components of a film (film poster, trailer, and even some parts of the film). 


\section{The Presence Arises From the Absence: The Kingdom of Lettering}

In the analysis of Turkish film titles, technology appears before us as a significant point of origin since both cinema and graphic design are technology-originated channels. Karamustafa (1999) pointed out that: "The development and transformation that graphic design, which is a communication medium, has gone throughout history show parallelism to the development of technological mediums" (p. 82). Answering the question whether there is a breaking or turning point of design that gives service in the field of cinema and the way of its reflection in titles, Türker İnanoğlu advocated a similar point to Karamustafa: "As we mention breaking or turning point, it is the best to basically check technological change and opportunities and move forward from that point" (as cited in Noyan, 2007, p. 48).

Prior to 1895, cinema in Turkey emerged as a new technology and entertainment type in almost the same period with Europe. In the first samples we have of the earliest films, like the sample which narrates Austrian Emperor's visit to Istanbul, we see that French and Ottoman letterings coexisted and elements such as frame was preferred as graphical component (see Figure 1). During those years, the shows were mostly prepared for the occupant forces in homeland and films were played under French inter-lettering. As the earliest professional attempt to apply graphic design in daily use, in 1909, the first advertisement agency Advertisement Collective Company, which can be accepted as a turning point for graphic design, was established in the ambiance of freedom ensured during the 2nd Constitutional Period. As an outcome of the failure to develop printing technology and tradition of commercial poster in the Ottoman, in topics such as charity foundations or theatre, there used to be more posters in Arabic letters. These were designs supported by ready-to-use illustrations or ornamented bordures. As if to draw attention to the cultural richness in Beyoğlu, Evren (1998) reminded that during the last days of Ottoman Empire, the handouts prepared for cinema shows were at times printed in six different languages (Romaic, Armenian, old Turkish, Hebrew, French, and English).

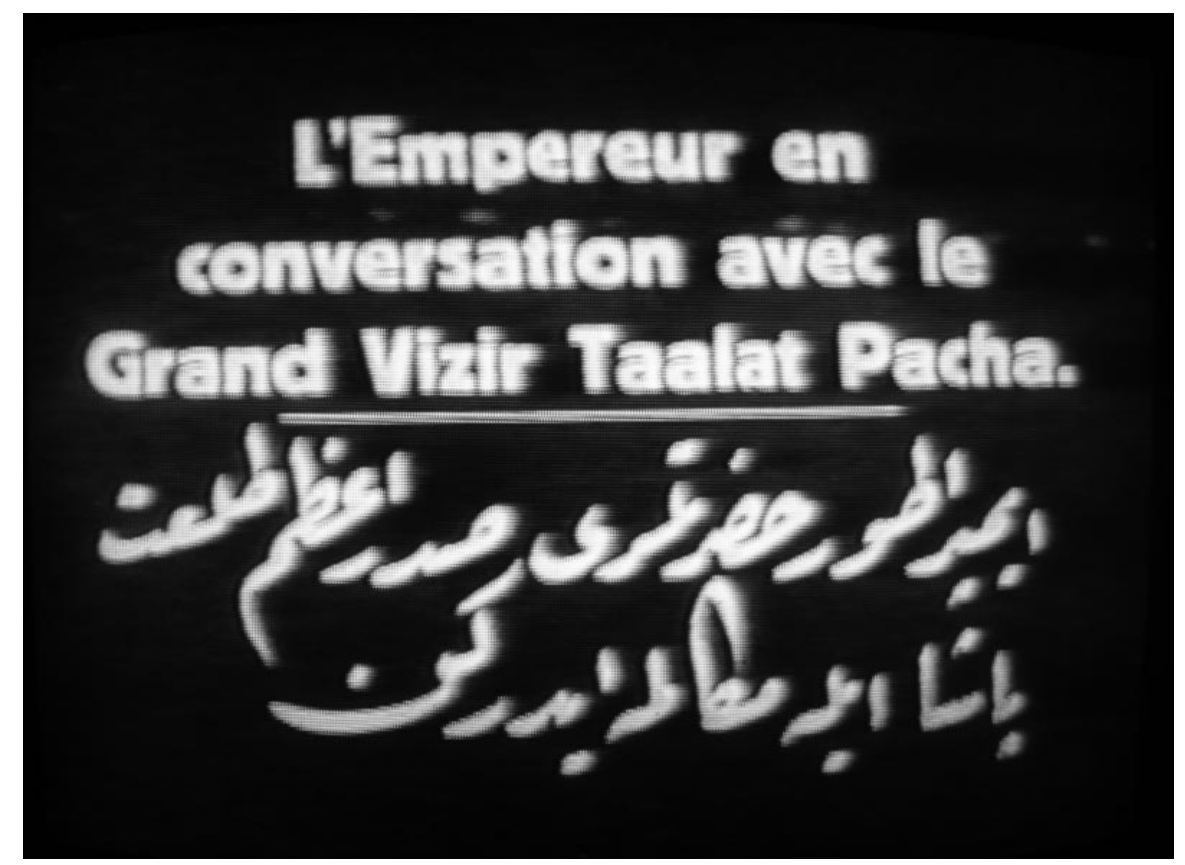

Figure 1. Inter-title example as the first film graphics from the times of Ottoman Empire. Source: Adapted from Sacha Film, Austria, 1917. 
The market demand of new Republic grew parallel to the new applications emerged with the new developments in industry. Since there were not any Turkish design samples or experienced designers available, most of the earliest design products such as label, package, poster, etc., were copied from Western samples, which were during those ages a component of visual culture by calligraphers, lithographers, metal workers, and talented printers. While Turkish Republic was witnessing major reforms in 1928, new Turkish letters were ratified. As a reflection of the great political, economical, social liveliness, and changes throughout the 1920s, it was clear that Turkish graphic design was also caught with the excitement of Westernization. There was an increase in the number of social, cultural, and commercial posters that can be defined as modern. However, despite the emergence of new visual opportunities as an outcome of these changes, there was not an independent development of graphic design yet. The Alphabet Reform inevitably affected cinema as well. A film distributor and cinema theatre owner Cemil Filmer (as cited in Çağlayan, 2004) narrated that the event negatively affected him, this decision, which was taken overnight, zeroed the value of old-lettered films and in the end he himself had to burn all the old-lettered film stocks. During those years, a great number of films were imported from America and Europe. Germans with Fritz Lang, Americans with Griffith and several other films stepped into Istanbul film market. As the audience watched these films, their visual taste became more sophisticated in both technical and artistic terms. Starting from 1923, Turkish inter-titles became prevalent. It is possible to assert that thanks to alphabet reform, Muslim Turkish people started to establish even closer relations with films. Parallel to the increase in sound cinema samples, inter-title era for Turkish audience came to an end.

During the period of 1923-1938, cinema was not included at all in the cultural politics of the new Republic. Çağlayan (2004) attributed the causes to the fact that cinema was not an independent sector then and since there was only one production company, there was not any competition and no market atmosphere where legal and financial regulations could be set. Nonetheless, starting from the early years of Republic, there was a heightened interest towards fine arts: The Academy of Fine Arts sent students to Europe for painting, sculpturing and music training as well as graphic design. According to Maden (1999) who stated that it would be unfair to deem that Turkish society lacked a cultural heritage or tradition from which it could build its art: The very same mistrust towards Turkish art and mentality is repeated in graphic design as well; instead of forming a unique identity by harmonizing strong aspects of traditional forms with modern sensitivity, by turning back on national sources Turkish graphic art is remodelled within ready-to-use pattern of the West.

The world went through a financial turbulence - Great Depression - in 1929 and protectionism of the state on economy started in Turkey. During the 1930s, Turkey went through a great social transformation with new revolutions and enactments. With regards to graphic design, in 1937 the Academy of Fine Arts exhibition and Florya posters were entitled to be the first artistic and professional posters prepared in academic environment. During the years of Second World War 1939-1945, although there was one sound film studio, which closely followed the standards of global film technology, until 1943 a period of stagnation was experienced since not even one single film was made (Çağlayan, 2004). The importers focused more on American films; however, since the road to Europe was closed, films were dispatched to Turkey via Egypt. On the road, Egyptian films were also added into packages. These films, which were mostly melodramas, received great admiration from the public. Those films contributed greatly to the formation of Turkish cinema. This powerful impact brought with itself a 
reaction as well. Criticized initially for injecting love of death instead of love of life, those Arabic films were censured by Inspection Commission from 1942 till 1957 on accounts of diminishing the love of Turkish language (Çağlayan, 2004). This censorship necessitated the formation of a new type in Turkish cinema to replace the popular films. The songs in Egyptian films were translated into Turkish and dubbed by local singers. Since a new profitable opportunity was introduced to popular Turkish cinema, it was also influential in putting an end to Ertuğrul-İpek film monopoly. It was during this period that in addition to the emergence of a Turkish cinema that reflected Egyptian films, new filmmakers who adopted technical and aesthetic values of American and European films also came to the scene. Following the war, division of cinemas into budget-specified classes, discount tickets, public-day screenings, promotions such as distribution of a henpeck diploma to the audience in 1947 for Vedat Örfi Bengü's film Kllıbıklar (Henpecked Husbands) are indicators of the facts that competition in cinema industry gained impetus and marketing strategies received greater significance. Despite all the negations caused by war, the Wealth Tax, 1939 dated Regulations on the Inspection of Films and Film Scenarios, cinema halls and audiences at this time showed $100 \%$ increase. In 1948, the first positive impact of the government was to decrease the tax on Turkish films, which resulted in an increased demand for Turkish films in Anatolian cinema halls, and inevitably a huge rise in the number of Turkish film productions and companies. Following the war, the improvement in the emotional state of society and economy, technological innovations, and availability of electricity and generators in Anatolia opened a new age for the cinema. Similarly an effect of industrialization attempts in Turkey was reflected positively in the field of graphic design as well. It can be seen that throughout modernization period the government was late to support cinema industry whereas it managed to back up the other branches of fine arts. While graphic design was promoted as an art branch, cinema developed as a separate commercial channel. So in the transition period from Ottoman Empire to Turkish Republic, how were the reflections of above-mentioned data on Turkish film titles? Title sequences of six Turkish films produced in the early period of Turkish cinema have been analyzed to find the answers.

The first title sequence analyzed is from the film Bir Millet Uyaniyor (A Nation Is Rising Up) (Muhsin Ertuğrul, 1932) (see Figure 2). One of the forerunners of war film titles with stars and flags concentrating on Turkish heroism and reflecting the common view of the age - the best films are the films of heroism narrating war - the aim is to make one feel that in those years when the excitement of struggle was still at its peak, the whole nation proudly shouldered the honour of Republic. Stars, which were included to typographic elements - although no other visual element was used - turned out to be a symbolic expression referring to crescent and star on Turkish flag once it united with the meaning of the film title. Besides, end titles, which were written in the same letters with opening titles but placed on a waving Turkish flag background, also support the aforementioned view. It was a common practice in those years to list the cast without giving surnames on the titles and posters. Artists and technical staff were referred with their first names or nicknames. During those years, Surname Law that banned Turkish families from using religious, social, familial, or nobility titles and instead introduced a second name common for each member of one family was not enacted yet. The little amount of credited technical staff may indicate the fact that the staffs were not that much eager to see their names on the film title or the ones preparing the film title were convinced that a small group was enough to show in the title. 

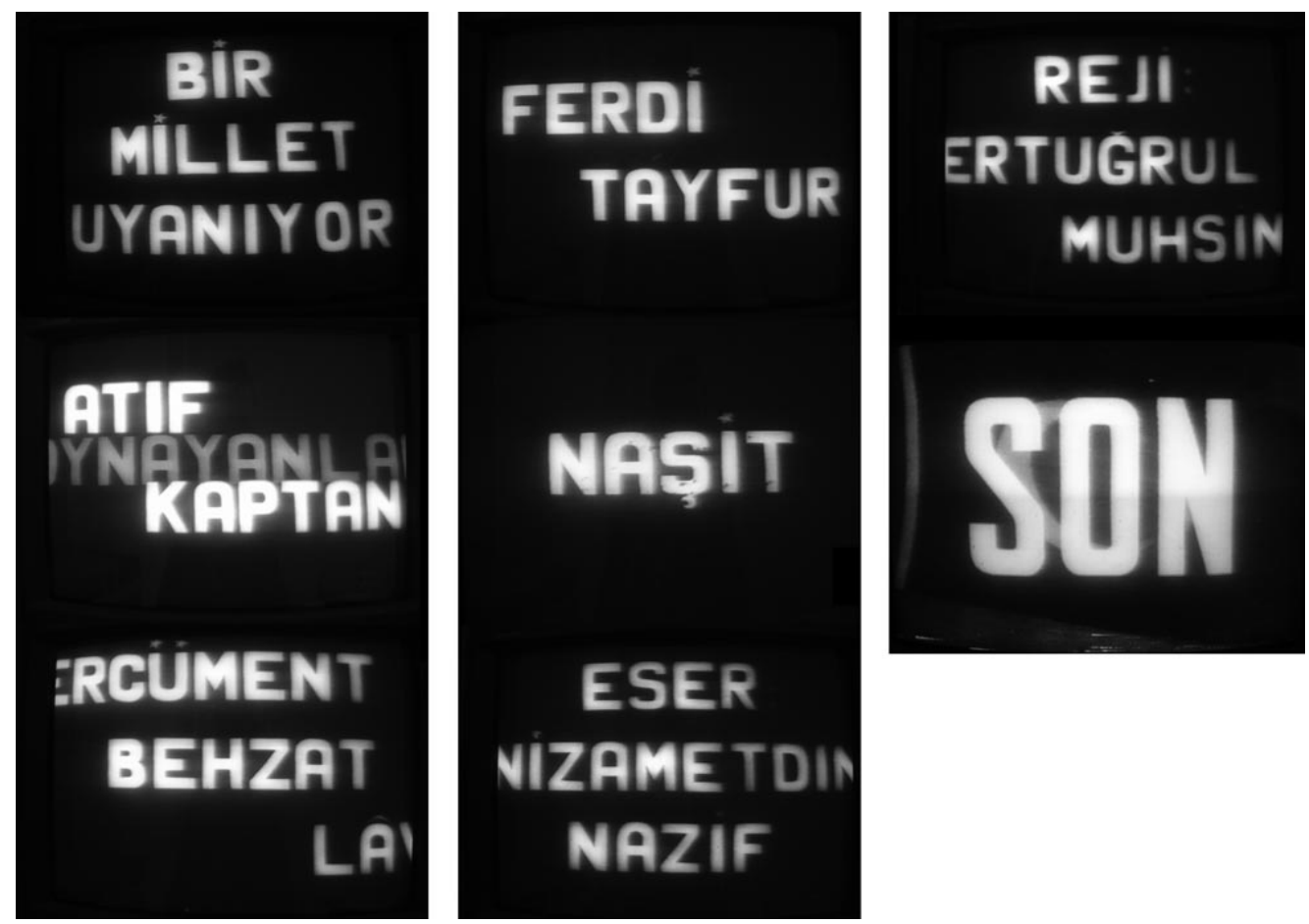

Figure 2. Opening and end titles, Bir Millet Uyanıyor. Source: Adapted from Ertuğrul, 1932.

The second title sequence to be examined is from Aysel, Batakl Damin Kizl (Aysel a Girl From Marshy Roof) (M. Ertuğrul, 1934-1935). In this title, sequence is believed to be first written on cardboard by hand then filmed, there was no motion; transitions were made as fade-in and fade-out. There was not yet in-detail copyright warning, running title sequence and use of dots—which were starting to emerge in samples abroad-however, the capital lettered logo of film company at the end of title sequence was an indicator of the ownership and rivalry. Regardless of the monotonous, simple, and neutral form of title sequence, use of capital letters in the whole title might indicate that the contributors to the film were paid heeds in the title sequence and people's attention would be drawn to these names thereby. Ülkü Erakalın attributed the lack of surnames in the title sequences of that age to the possible failures in implementing Surname Law in its fullest sense (personal interview, Istanbul, April 3, 2006). The expression "A Village Story" came right after the title of the film and the word "story" here emphasized the fictitious style of the film hence enabled an actual promotion and introduction to the film by identifying the plot.

Just like the mixed character of Yeşilçam which represented a production model and period in Turkish cinema, Turkish film posters were at first under the influence of German, French, and later Hollywood, Italy, Mexico, India, and Egypt film posters. During the early years of cinema in title sequences an outlook to abroad, in cinema posters and title sequences an imitation of foreign samples and influence of art and design movements like Art Deco were attracting attention. The first co-product and sound film of Turkish cinema Istanbul Sokaklarında (On the Streets of Istanbul) (Ertuğrul, 1931, Turkey, Egypt and Greek co-production)—its title sequence is not available - clearly bears the effects of geometric and simple style of Art Deco. It is also possible to assert that it had a distinctive influence compared to the film posters, which was mostly hand-produced by primitive techniques in the following periods (see Figure 3). 


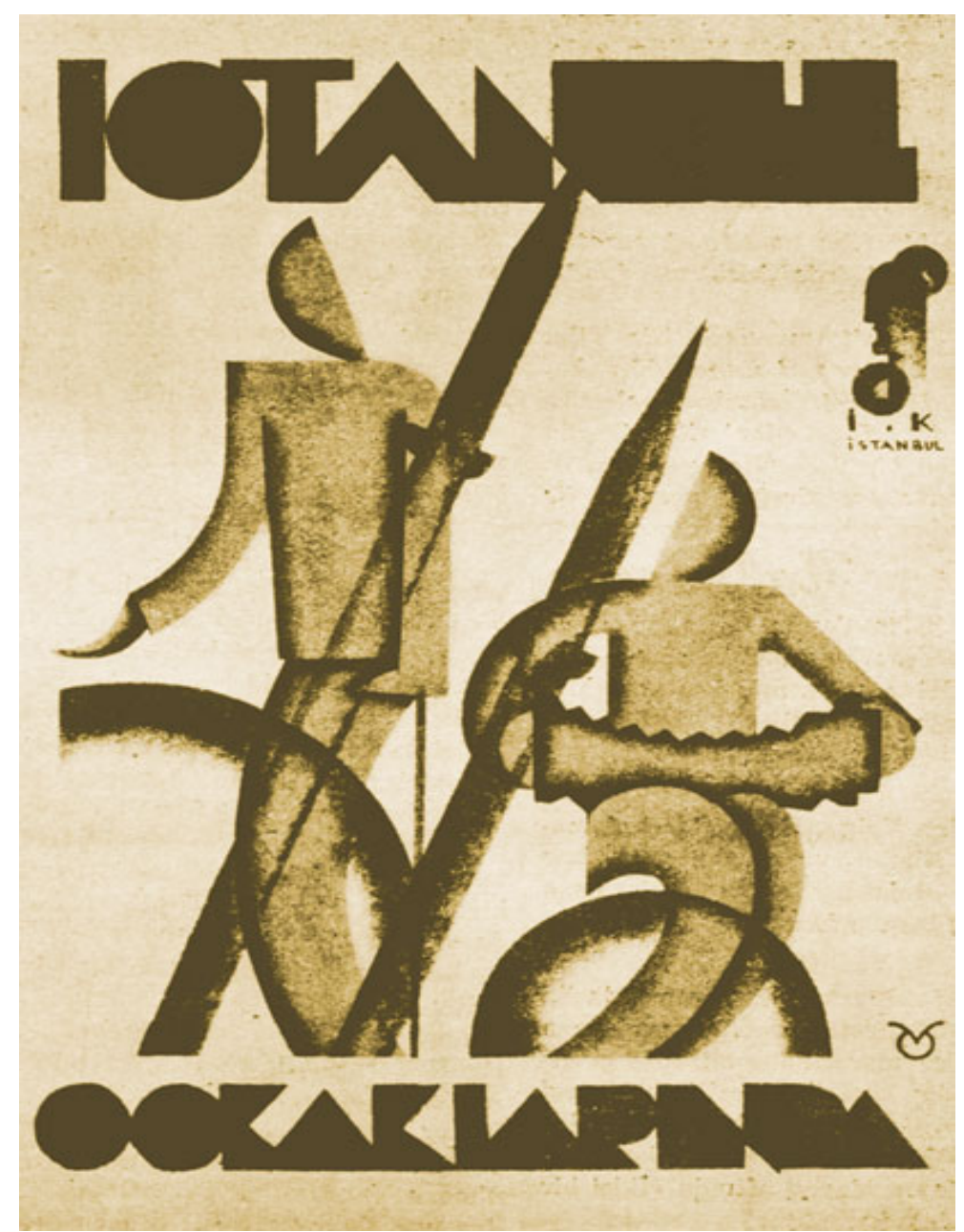

Figure 3. Poster, İstanbul Sokaklarında. Source: Adapted from Ertuğrul, 1931.

The film titles of Şehvet Kurbanı (Victim of Lust) (Ertuğrul, 1940) with its illustrative and typographic characteristics reminding Art Deco graphic style is similar to aforementioned film poster and title of Kahveci Güzeli (Lady of the Coffee House) (Ertuğrul, 1941) which was projected for the next year (see Figure 4). The dots and running title sequence employed are imitations of foreign samples too. In the 1930s, particularly in Hollywood films use of dots and Art Deco typefaces were prevalent. Hence, we can deduce that filmmakers were closely watching the foreign films and visual styles. The names, which were deemed significant, were indicated with contoured, sanserif letters and inter-titles were written with a font reminiscent of decorative handwriting and when a hierarchical distinction was enabled, a third font was used to show secondary artists. Background illustration and front information were contextually matched up. Throughout the film as well, the same typeface, which was coordinated with title sequence and sub-letterings, were employed. In illustrations, film characters were introduced to the audience as silhouettes. The connection between back and front stage that was visible within lettering and illustrations makes one feel that there was a conscious will in selection and design. In the poster, not the composition but rather the quality of illustration and the elements and symbols employed in reflecting the theme of the film enable us to state that title graphics were finer and better than poster graphics and illustrations of the film (see Figure 5). There is not a binding condition between poster and title sequence. 

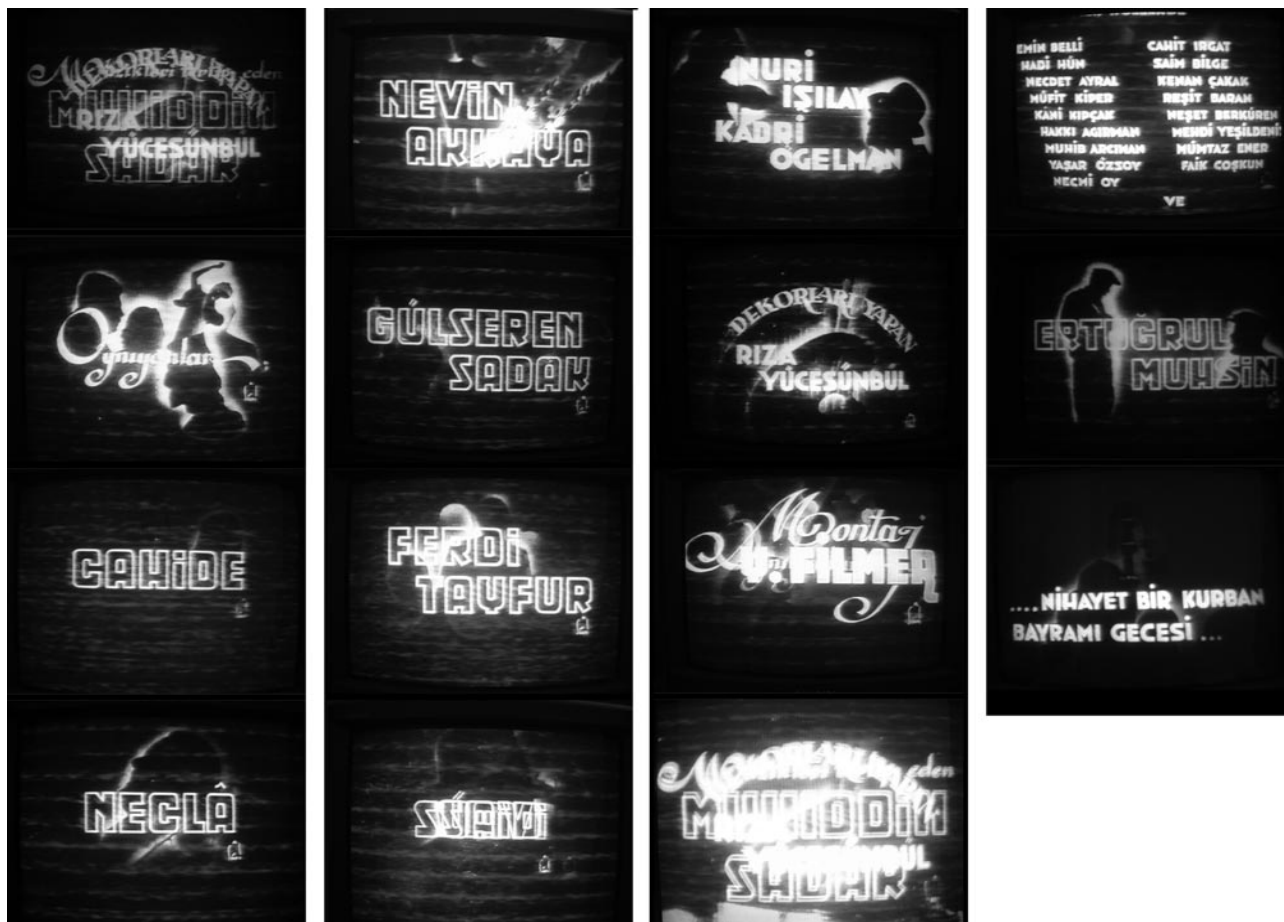

Figure 4. Opening titles, Şehvet Kurbanı. Source: Adapted from Ertuğrul, 1940.

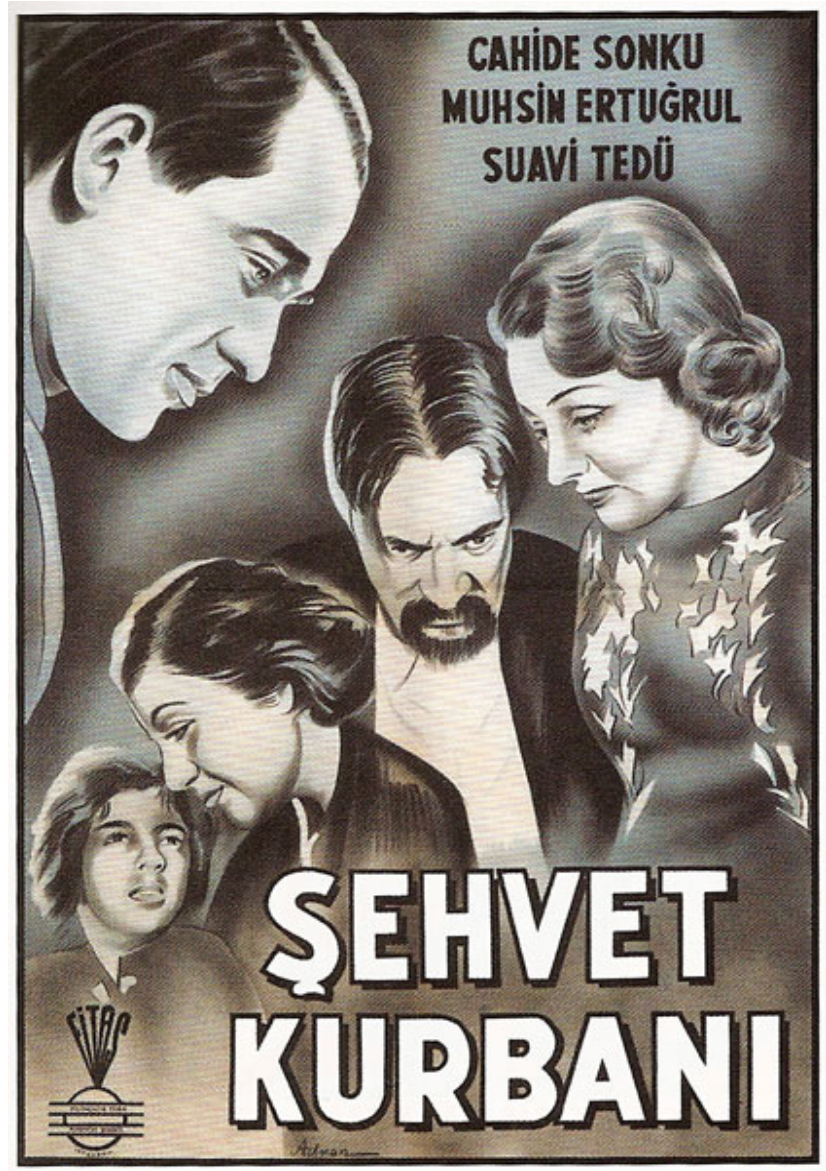

Figure 5. Poster, Şehvet Kurbanı. Source: Adapted from Ertuğrul, 1940. 
In the title sequence of Kahveci Güzeli (Lady of the Coffee House) (Ertuğrul, 1941) with the expression "presents its fairy tale", the film establishes a connection with the world of fairies or in other words the imaginary world. The statement "The events told in this story are inspired from a very old Turkish fairy tale" can be seen in the very first film frame coming after the sequence was written in a decorative manner resembling hand-writing, hence, the epic influence was strengthened. The illumination of the lettering in title sequence and use of first names of the main artists supported the epic reflection. Although Surname Law was enacted in 1934, when the names were first written on screen, their surnames were missing which may be attributed to the fact that specific law was not thoroughly adopted yet or the aim might have been to reinforce epic reflection by omitting surnames and using given names or titles instead.

This reference attributed to the fairy or imaginary world may be regarded as a reflection of the harsh years of war when the film was shot. In the title the expression that emphasizes songs “... composing the songs... " can be interpreted as the connection of cinema-an entertainment form-with music and perceiving it within this framework. Furthermore, the expression "film composer" in the title refers to film music; "film shooter" is the equivalent of cinematographer or cameraman. The word "... presents" like “... introduces" are the examples of an ownership certificate or signature. In fact, title sequence, which can be regarded as a whole indication of signature, may be indicator of the ownership of an art work just like the autograph put on the right bottom of paintings. The signature, which indicates ownership, can also be viewed as blessing the work. This blessing at the same time functions as a value adder yet signature also means responsibility and it exposes the name in charge. The explanation of the word "Turkish" on the specific poster is related to the abundance of Egyptian films on cinemas during that period and the misleading visuals on film poster (Gür, personal interview, Istanbul, November 26, 2007).

An example to the differences title sequence created in technical sense is Fato/Ya Istiklal Ya Ölüm (Fato, Either Freedom or Death) (Turgut Demirağ, 1949). In this sequence, the title of film company "And" appears as a motion visual effect appearing and vanishing from the bottom to the top. Besides, the bomb that explodes at the very moment film title appears on the sequence is backed up with a bomb noise effect which strengthens the moment company name appears. In this form, it is possible to say that title sequence was taken into consideration and the movie was designed in a way to appeal to the audience technically and contextually. Instead of harsh and bold letters that remind of war, typeface selection is feminine, softer and more emotional. That way, background images like tent, bridge, explosion, fire, smoke, etc., are softened. It is possible that such emasculation made it possible to achieve a connection with the female audience by underlining the love story and romance in the film. In film poster, music and film agent and director, which were, the titles used in sequence can be seen. The music and film director were in the same hierarchy. "And"-like the title sequence - appears on the poster too with its logo. All together, they prove the fact that company title and the meaning attributed to music in titles are not coincidental.

In the title sequence of Vurun Kahpeye (Strike the Whore) (Lütfi Ö. Akad, 1949), motion effect was performed only via page-turning jest. The arrangement in the beginning title sequence, typography, effects, and detailed credits leave an impression that title sequence was emulated. Aside from the fact that it was a novel adaptation, the title sequence speaks it aloud that main character is an intellectual teacher and the film is centered on education. Regarding the expression "national novel" and page turning action, İnanoğlu (as cited in Noyan, 
2007) asserted that it is not a must to have read the scenario to prepare poster or title sequence but in order to use in design, it is necessary to know something about the film, to feel its ambiance. He also added that in the past, designing the title sequence of a novel adaptation-like the famous writers of the age Muazzez Tahsin Berkant or Kerime Nadir - like the pages of a book would lead the audience to have an experience parallel to the film of a literary work. Needless to say that in addition to reinforcing the context of film, this approach also adds a dynamic and distinctive ambiance to the title sequence, which could otherwise be quite monotonous. The film poster does not have a graphical connection with title sequence. However, it is interesting to note that although the name of designer was written on poster, title sequence designer was not mentioned in detailed credits. However both seemed to be the products of a meticulous practice.

\section{Conclusions}

We have limited numbers of film copies belonging to the early years of Turkish cinema. Based on this restriction, it is quite difficult to make interpretations regarding that age since title sequence and sound tracks of available old films are lost or damaged. Therefore, some of them have been remade and composed of false data (Scognamillo, personal interview, İstanbul, November 8, 2006). Title sequences we discussed hereby are samples of films with a national character that emerged during the late 1940s and films that mostly appealed to low and middle class audiences. Based on the deduction of Kahraman (2004): "The near history of Turkey is actually a visual one, because Turkish modernization initially started as a reality associated with vision", we can assume that cinema and visual culture are the components nourishing this reality. Within this context, it is possible to conclude that based on the symbols and expressions frequently shown in title sequences, cinema owns a structure driving national feelings and embracing public values. Furthermore, these credits tell a lot about the state of cinema industry in those times, such as the fact that cinema was viewed as a musical entertainment: As the credited names in film titles increased in number throughout the years and the musicians in particular were emphasized more.

In the titles of this first period when typographic elements were fore-grounded, the common features are dark background, white lettering written by painters and the use of dots between artists' names and the character they play. This dotted feature of title sequences that reminds a printed book's context may be a feature transferred from book design to graphic design for cinema. In the early years title sequence was, in dry terms, just like a package - similar to the colophon -printing data and index of the book and "son" at the end. Opening titles were preferred, the word "son" (the end) indicating the final of film was considered important. Kurdoğlu asserted that the word "son" was preferred since during that period when cinematic narrative language lacked a wide consensus unlike today, it was hard to estimate where the film ended (personal interview, Istanbul, April 17, 2006).

Aside from those, a very significant common point is that title sequences are composed of inactive, fixed images. Yet there is an attempt to activate this monotony by several methods. Amongst them are fade-in and fade-out in transitions and up-and-down sliding effects. Yurdaer Altıntaş stated that, earlier in the posters and title sequences typography was mostly hand written and sanserif typefaces were preferred for their applicability to hand use, and easiness was, rather than applicability to the film content, considered more (personal interview, Istanbul, March 8, 2006). However, motives like stars and several typefaces with symbolic references that could 
reinforce the meaning were also popular. Related to the process in this period Tonguç Yaşar also stated that since until the 1950s there was no "Letraset", title sequences were handwritten on cardboard and before shooting the film, since the directors only presented the names of players, team, team names and synopsis in hierarchy and it was called first or secondary cardboard (personal interview, Istanbul, March 25, 2006). Necip Sarıcıŏlu also mentioned that basically titles are the responsibility of studio where there are title sequence shooting and camera rooms. He also explained the dominant production process of titles as title sequence was first filmed as positive, then washed, made transparent and superposed over a background (personal interview, İstanbul, April 6, 2006).

Film title conveys graphic design elements such as type, colour, texture, etc.. But at the same time it conveys cinema elements such as sound and motion. It is not only a symbolic and aesthetic expression, but also a channel that has commercial and industry-specific necessities. Both design and cinema depend on good planning and rely on budget as well as technology. Both of them focus on the users/audiences. Even though the rational and functional structure of design continues in the area of film title, it moves towards a more abstract area that includes storytelling, dramatic elements and time. Film poster, film title, and DVDs are channels in which cinema meets the user, the function and what is concrete. In this period, there seems to be no conscious relation and consistency built between the film titles and film posters. It can also be said that the connection amongst the different divisions of labour within the film industry is week and the making and promotion of a film are not perceived and handled altogether. Yet, although the people making the titles and posters were not from design schools, nor they are well acclaimed graphic designers, the popular design styles such as Art Deco seems to grab the attention of and influence these labourers as well as the design school graduates.

Turkish film titles form categories related to some of the film genres (national heroism stories, literary love stories, etc.) and the elements of design and symbolism related to these genres. Another classification in film titles may be possible according to their designers and typographic application techniques: The titles of the early years can be defined as "Hattat", calligrapher titles where as the following periods can be classified as the titles of hand-drawn type and plastic letters by artists, caricaturists, and illustrators, and later titles of "Letraset" and photo typesetting by photographers, cameramen, technical staff, film editors, and finally digital lettering by designer and visual effect artists. Apart from going through phases with regard to timing, budget, and technology, the film titles in Turkish cinema developed in line with the division of labour in the production process, awareness for titles, the infrastructure of the designers and the film industry. Throughout this process and development, the previously anonymous film title designers became designers with names. The people who were making the film credits transformed into individuals who were in the film credits. Similarly, film titles developed as designs, which had a specific, original, and different identity that was not anonymous or indifferent.

Due to the lack of time, technical and financial deficits, neglecting or ignoring the significance of title sequence within the film; title sequence could not perform its function as a warmer to the film atmosphere. Nonetheless all these negative conditions, in the following years as some of the analyzed titles also put forward-applications that were, within the limits of technology, close to foreign samples and trials were conducted. In this context, what Esen Karol argued is meaningful: "It's impossible to discuss the paintings of a country when we can not discuss concepts... If there is an impasse, this is in general a cultural one" (as cited in Tanyeli, 2007, p. 73). Overcoming the danger of creating similar designs and getting away from the ordinary are possible with the creation of strong concepts. Media planning, communication design, and design management 
enter the area of graphic design and cinema. Developments in these also change concepts and reshape film title design. While film title designer Wayne Fitzgerald describes the innovation attempts and the search in film title design, his words seem to summarize the adventure of the Turkish film titles: "There were things that could be done with film; it was crazy not to do them" (Billanti, 1982, p. 68). In this period of Turkish cinema that has been studied, the paths of graphic design and cinema have not fully crossed yet. Nevertheless, they were the creations of two newborn disciplines and a newborn country. Therefore, they were naïve, sincere, curious, and eager to try. It seems that Turkish cinema and design have learnt from each other as well but still have a lot more to learn.

\section{References}

Allison, D. (2006). Novelty title sequences and self-reflexivity in classical Hollywood cinema. Retrieved from http://www.latrobe.edu.au/screeningthepast/20/novelty-title-sequences, html

Bass, S. (2001). Bass on titles (Short 11 extacy) [DVD]. L.A.: Quickbands Networks.

Billanti, D. (1982, May/June). The names behind the titles. Film Comment, 18(3), 68.

Çağlayan, T. A. (2004). Audience-film interaction and audience profile in Turkish cinema (Dissertation, Mimar Sinan University, Institute of Social Sciences, Film and TV Department, Film and TV Program, Istanbul).

Evren, B. (1998). Beyoğlu in time (Beyoğlu Zaman Iç̧inde) (Part 5) [TV Documentary]. Turkey: TRT.

Helfand, J. (2001). Screen: Essays on graphic design, new media, and visual culture (pp. 119-123). New York: Princeton Architectural Press.

Kahraman, H. B. (2004, May 6). Lessons from the illustrated history (Resimli tarih’ten dersler). Radikal Newspaper.

Karamustafa, S. (1999). The last quarter century of graphic design in Turkey. In A. Ödekan (Ed.), The colours and forms of the republic. Istanbul: Tarih Vakfı Yayınları.

Maden, S. (1999). The yesterday and today of the graphic arts (Grafik sanatının dünü, bugünü). In A. Ödekan (Ed.), The colours and forms of the republic (Cumhuriyetin Renkleri, Biçimleri). İstanbul: Tarih Vakfı Yayınları.

Mueller, G. M. (2006). The image is the message: A model for applying iconology in mass media research. International Communication Association Conference. Dresden.

Noyan, N. E. (1998). Representing romance: An investigation of design and signification in the posters of Turkish melodrama 1965-1975 (Master's thesis, Bilkent Üniversitesi, Ankara).

Noyan, N. E. (2007, August). History through film posters: Türker İnanoğlu. Grafik Tasarım, 11, 46-49.

Panofsky, E. (1983). Meaning in the visual arts. Chicago: University Of Chicago Press.

Sacha Film. (1917). Austrian emperor's visit to Istanbul. Austria.

Tanyeli, U. (2007, May). Profil: Esen Karol. Arredamento Mimarlık, 5, 58-73.

van Leeuwen, T. (2001). Semiotics and iconography. In T. van Leeuwen \& C. Jewitt (Eds.), Handbook of visual analysis (pp. 92-118). London: Sage.

van Straten, R. (1994). An introduction to iconography: Symbols, allusions and meaning in the visual arts. London: Routledge. 